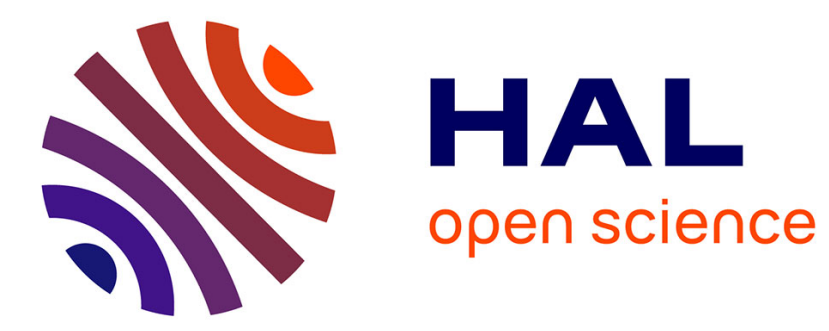

\title{
Transduction of baculovirus vectors to queen honeybees, Apis mellifera
}

Takashi Ikeda, Jun Nakamura, Seiichi Furukawa, Panuwan Chantawannakul, Masami Sasaki, Tetsuhiko Sasaki

\section{- To cite this version:}

Takashi Ikeda, Jun Nakamura, Seiichi Furukawa, Panuwan Chantawannakul, Masami Sasaki, et al.. Transduction of baculovirus vectors to queen honeybees, Apis mellifera. Apidologie, 2011, 42 (4), pp.461-471. 10.1007/s13592-011-0014-z . hal-01003545

\section{HAL Id: hal-01003545 \\ https://hal.science/hal-01003545}

Submitted on 1 Jan 2011

HAL is a multi-disciplinary open access archive for the deposit and dissemination of scientific research documents, whether they are published or not. The documents may come from teaching and research institutions in France or abroad, or from public or private research centers.
L'archive ouverte pluridisciplinaire HAL, est destinée au dépôt et à la diffusion de documents scientifiques de niveau recherche, publiés ou non, émanant des établissements d'enseignement et de recherche français ou étrangers, des laboratoires publics ou privés. 


\title{
Transduction of baculovirus vectors to queen honeybees, Apis mellifera
}

\author{
Takashi IKEDA ${ }^{1,4}$, Jun NAKAMURA ${ }^{2}$, Seiichi FURUKAWA ${ }^{1}$, \\ Panuwan CHANTAWANNAKUL ${ }^{3}$, Masami SASAKI ${ }^{1,2}$, Tetsuhiko SASAKI ${ }^{1,2}$ \\ ${ }^{1}$ Brain Science Institute, Tamagawa University, Tamagawagakuen, Machida, Tokyo 194-8610, Japan \\ ${ }^{2}$ Honeybee Science Research Center, Research Institute, Tamagawa University, Tamagawagakuen, Machida, Tokyo \\ 194-8610, Japan \\ ${ }^{3}$ Faculty of Science, Chiang Mai University, Chiang Mai 50200, Thailand \\ ${ }^{4}$ Department of Regenerative Medicine, Research Institute, National Center for Global Health and Medicine, \\ Toyama, Shinjuku, Tokyo 162-8655, Japan
}

Received 24 December 2009 - Revised 23 August 2010 - Accepted 24 August 2010

\begin{abstract}
The potential uses of baculovirus as a gene vector to queen honeybees were examined in this study. We used a green fluorescent protein-expressing baculovirus with wild-type envelope and two pseudotype viruses of which one overexpressed GP64 and the other expressed a virion protein of a honeybee virus on the envelope. After injection of these baculoviruses into queen pupae, infection was detected in the fat bodies, but not in the ovaries. Pupae injected with a titer of $1 \times 10^{5}$ infectious units survived to eclose, and the infection was also detected in the fat bodies of adult queen honeybees, suggesting that baculoviruses can transiently express genes in the fat bodies, and therefore, can be used for further analysis of gene functions. In addition, although the viruses examined in this study failed to express the reporter gene in the ovaries, the infection in the fat bodies suggests that baculoviruses could be potentially useful for transgenesis, if appropriately developed.
\end{abstract}

honeybee / virus vector / gene transfer / transgenesis / pseudotype

\section{INTRODUCTION}

Insect transgenesis is important for studies on gene functions and is essential in the establishment of useful transgenic insects. For stable transgenesis to occur, exogenous genes must be introduced into germ line cells. A common method to introduce an exogenous gene into the genomes of insect germ line cells is embryonic microinjection of two plasmids: a helper plasmid carrying a transposase gene originating from a transposon such as $P$ element or piggyBac and a donor plasmid carrying the gene of interest inserted between a set of recognition sites of

Corresponding author: T. Sasaki,

tsasaki@lab.tamagawa.ac.jp

Manuscript editor: Monique Gauthier the transposase (reviewed by Handler 2001; Kimura 2001; Handler 2002). Using this technique, transgenic lines have been established in various insect species, including Drosophila melanogaster (Rubin and Spradling 1982), Bombyx mori (Tamura et al. 2000), Aedes aegypti (Coates et al. 1998; Jasinskiene et al. 1998), Anopheles gambiae (Grossman et al. 2001), Culex quinquefasciatus (Allen et al. 2001), Tribolium castaneum (Berghammer et al. 1999), Ceratitis capitata (Loukeris et al. 1995), Athalia rosae (Sumitani et al. 2003), and Bicyclus anynana (Marcus et al. 2004). In addition to embryonic microinjection, exogenous genes can also be introduced into cells by utilizing the infection ability of certain viruses, such as the baculovirus Autographa californica nucleopolyhedrovirus (AcNPV), whose natural 
host is the alfalfa looper moth, A. californica. The AcNPV genome is a double-stranded DNA that is maintained extrachromosomally in host cells. Successful gene transduction into germ line cells has been performed using two recombinant AcNPVs: a helper virus carrying a transposase gene and a donor virus carrying the gene of interest within the recognition sites (Yamamoto et al. 2004; Kawashima et al. 2007).

The European honeybee, Apis mellifera L., is a beneficial insect that provides useful products and mediates the pollination of agricultural plants. The honeybee is also an interesting model organism for basic biology to explore the insect sociality and brain function because it has a sophisticated eusociality and exhibits high abilities of learning, memory, and communication. Several molecular biological studies can be performed using the honeybee. The whole genome sequence of the honeybee has been determined (Honeybee Genome Sequencing Consortium 2006), and microarrays are available for genome-wide expression analyses. In addition, RNA interference (RNAi) is useful in determining gene functions of honeybees (Amdam et al. 2003; Nunes and Simões 2009). However, a method to produce transgenic honeybees has not been established. This is partly because the honeybee larvae are naturally grown in hives and cared for by workers and handling of eggs or larvae in the laboratory is laborious, even though possible (Robinson et al. 2000; Aase et al. 2005; Patel et al. 2007; Kucharski et al. 2008). To date, only transient expressions of exogenous genes have been reported for the honeybee using techniques such as electroporation of adult brain cells (Kunieda and Kubo 2004), instrumental insemination of sperm mixed with a plasmid (Robinson et al. 2000), and injection of an AcNPV vector into worker larvae and pupae (Ando et al. 2007).

Wild-type baculovirus forms two types of virions: occlusion-derived and budded virions of which the latter is utilized as a gene vector. The budded virion is surrounded by a phospholipid bilayer (envelope) that contains membrane proteins. The major envelope protein, GP64, is critical for attachment to host cells, induction of endocytosis, membrane fusion and budding of the virus (Volkman and Goldsmith 1985; Blissard and Wenz 1992; Hefferon et al. 1999; Oomens and Blissard 1999). The infectivity of a baculovirus can be manipulated by modifying GP64, e.g., overexpression of this protein drastically increases the infection of baculovirus to mammalian cells (Tani et al. 2001, 2003). The infectivity to mammalian cells can also be enhanced by displaying a virion protein of a mammalian virus outside the envelope as a fusion protein with GP64; this technique is referred to as the surface display method (Boublik et al. 1995; Ernst et al. 2006; Matilainen et al. 2006).

One approach that can be used to obtain a transgenic honeybee line is to integrate an exogenous gene into the gonads of individuals with reproductive potential. In this study, we examined the ability of a baculovirus to infect queen honeybees and evaluated its ability to transiently express genes in queen honeybee tissues especially in the ovaries, which is an essential process for mediating the integration of an exogenous gene into the genome using a helper/donor system. To achieve these objectives, we used queen pupae with actively developing ovaries and examined the following: (a) infectivity of the baculovirus into queen pupae and its effect on host viability and (b) whether the tropism of this virus to the ovaries is increased by GP64 overexpression or the surface display of a virion protein of the honeybee deformed wing virus (DWV). We injected a baculovirus with wild-type envelope and two pseudotype viruses into queen pupae and detected the infection of these viruses in the fat bodies, but not in the ovaries. The potential uses of baculoviruses as gene transfer vectors for queen honeybees are discussed.

\section{MATERIALS AND METHODS}

\subsection{Preparation of recombinant baculoviruses}

First, plasmids containing the insertion sequences shown in Figure 1a were prepared. A green fluores- 
cent protein (GFP) expression cassette was amplified by a polymerase chain reaction ( $\mathrm{PCR}$ ) from the pAcGFP1-C1 plasmid (Clontech, Palo Alto, CA, USA) and ligated into the pENTR/D-TOPO plasmid (Invitrogen, Carlsbad, CA, USA) to obtain pENTR/ WT/GFP. The polyhedrin promoter $\left(\mathrm{P}_{\mathrm{PH}}\right)$, gp64 coding sequence, and SV40 poly(A) signal were amplified by PCR and inserted into $\mathrm{pENTR/WT/GFP}$ to obtain the pENTR/64+/GFP plasmid. PCRamplified $\mathrm{P}_{\mathrm{PH}}$, gp64 signal peptide sequence, coding sequence of DWV virion protein 1 (VP1; see below), and gp64 mature protein sequence were ligated to form a VP1 surface display cassette. This cassette was subsequently inserted into the pENTR/WT/GFP to construct a $\mathrm{pENTR/VP1/GFP} \mathrm{plasmid.}$

Second, recombinant baculoviruses (AcNPV) designated WT/GFP, 64+/GFP, and VP1/GFP were prepared using these constructed plasmids and the BaculoDirect Baculovirus Expression System (Invitrogen) according to the manufacturer's recommendations. The plasmids were recombined with baculovirus genomic DNA using LR clonase II (Invitrogen) to replace the polyhedrin coding sequence of the baculovirus genome with the insertion sequences of the plasmids. Subsequently, the recombinant virus DNA was transfected into Sf9 cells (Invitrogen), an AcNPV-permissive insect cell line derived from Spodoptera frugiperda. Viral virions that budded from the cultured cells were concentrated by centrifugation of the culture media at $144,000 \times g$ for $1 \mathrm{~h}$ (Tani et al. 2001) and resuspended in phosphate-buffered saline (PBS; $137 \mathrm{mM} \mathrm{NaCl}, 8.1 \mathrm{mM} \mathrm{Na}_{2} \mathrm{HPO}_{4}, 2.68 \mathrm{mM} \mathrm{KCl}$, $\left.1.47 \mathrm{mM} \mathrm{KH} \mathrm{KH}_{4}, \mathrm{pH} 7.5\right)$. Titers of the viral solutions were determined as infectious unit (IFU) using the BacPAK Baculovirus Rapid Titer Kit (Clontech).

\subsection{Isolation of DWV VPI}

Total RNA was extracted from an adult worker honeybee with deformed wings using the Total RNA Isolation System (Promega, Madison, WI, USA). First-strand cDNA was synthesized using SuperScript III (Invitrogen) and a gene-specific primer DWV_VP1_SmaI_R (5'-TCC CCC GGG TTC TGG AAT AGC CTC AAT AAA-3'). The full-length cDNA of DWV VP1 (accession no. AY292384; Lanzi et al. 2006) was amplified using the primers DWV_VP1_KpnI_F (5'-CGG GGT ACC GAT AAT a

WT/GFP

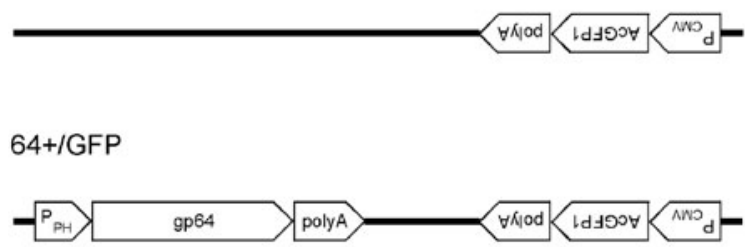

VP1/GFP

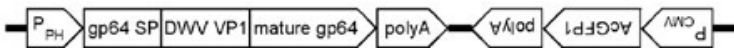

b
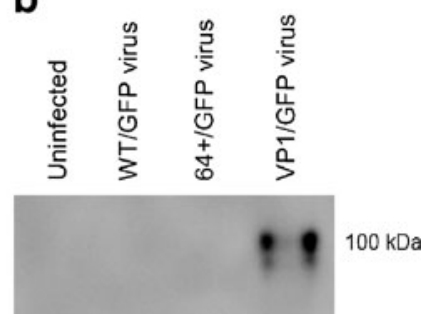

GP64

Figure 1. Baculovirus vectors inoculated into queen honeybees. a Structures of insertion sequences used. WT/GFP carries a GFP expression cassette comprising a cytomegalovirus immediate-early gene promoter $\left(\mathrm{P}_{\mathrm{CMV}}\right)$, Aequorea coerulescens GFP gene (AcGFPl) and SV40 poly(A) signal. The GP64 overexpression cassette in $64+/ \mathrm{GFP}$ consists of the polyhedrin promoter $\left(\mathrm{P}_{\mathrm{PH}}\right)$, gp64 coding sequence, and SV40 poly(A) signal. VP1/GFP has the deformed wing virus (DWV) VP1 coding sequence in the 64+/GFP cassette between the GP64 signal peptide sequence (SP) and GP64 mature protein sequence. b Western blot analysis of Sf9 cells infected with recombinant baculoviruses. Sf9 cells were subjected to Western blot analysis using an anti-GP64 monoclonal antibody at 3 days after infection with recombinant baculoviruses. 
CCT TCT TAT CAA CAA-3') and DWV_VP1 SmaI_R. The PCR product was cloned and sequenced to confirm its identity.

\subsection{Western blot analysis}

Sf9 cells were infected with the recombinant viruses (see above) at a multiplicity of infection of 0.4 , and $1 \mathrm{~mL}$ of each cell culture was collected by centrifugation 3 days after infection. Cells were lysed with $100 \mu \mathrm{L}$ of an SDS-PAGE sample buffer $(50 \mathrm{mM}$ Tris-HCl, 2\% SDS, $6 \% \beta$-mercaptoethanol, $12 \%$ glycerol, $0.025 \%$ bromophenol blue, $\mathrm{pH}$ 6.8) and boiled. A $0.1-\mu \mathrm{L}$ aliquot of each protein sample was subjected to Western blot analysis. Western blotting was performed according to the method of Towbin et al. (1979) with modifications. The blotted membrane was incubated with an anti-GP64 monoclonal antibody (Cosmo Bio, Tokyo, Japan) and subsequently with a horseradish peroxidase-conjugated, affinity-purified goat antimouse IgG2b antibody (Cosmo Bio). Immunoreacted bands were detected using a VersaDoc Imaging System (Bio-Rad Laboratories, Hercules, CA, USA).

\subsection{Rearing of queen pupae and virus injection}

Queen honeybees were reared by transferring 1st instar larvae to artificial plastic queen cell cups. Queen larvae undergo four larval molts at approximately 24$\mathrm{h}$ intervals. Following the last larval molt, the queen cell is sealed and the queen larva completes pupation about 3 days after the cell is sealed (Laidlaw and Page 1997). Pupal development in the queen honeybee takes about 5 days. To inoculate the virus, queen pupae were collected 4 days after the cells had been sealed (8-9 days after the transfer of the larvae to the queen cell cups) and injected with the viral solutions into the abdominal region using a 33-G needle (TERUMO, Tokyo, Japan). The injected queen pupae were placed on a filter paper in a 6-well plate and kept in an incubator at $33^{\circ} \mathrm{C}$ and $70 \%$ relative humidity.

\subsection{Analysis of reporter gene expression in adult fat bodies}

Transcription of $g f p$ was assessed in the fat bodies of adult queen honeybees injected with WT/GFP at the pupal stage. Abdominal carcasses (integument and subjacent fat body) were collected by removing the entire digestive system and the ovaries from queen honeybees at $24-48 \mathrm{~h}$ after eclosion. These carcasses were used as the source of fat bodies (Bitondi et al. 2006). Total RNAs were extracted using the RNeasy Mini Kit (Qiagen, Valencia, CA, USA) and reverse-transcribed (RT) using SuperScript III and oligo(dT) 20 primer (Invitrogen). A partial 400bp $g f p$ sequence was PCR-amplified using the primers 5'-GCA GTG CTT CTC ACG CTA C-3' and 5'-CAG GTA GTG GTT ATC GGG C-3'. A 181bp fragment of a $\beta$-actin sequence (AB023025) was amplified using primers 5'-AGG AAT GGA AGC TTG CGG TA-3' and 5'-AAT TTT CAT GGT GGA TGG TGC-3' (Chen et al. 2005a) and used as a positive control. PCR cycle conditions were as follows: $94^{\circ} \mathrm{C}$ for $5 \mathrm{~min}$ followed by 25 cycles of $94^{\circ} \mathrm{C}$ for $30 \mathrm{~s}, 56^{\circ} \mathrm{C}$ for $30 \mathrm{~s}$ and $72^{\circ} \mathrm{C}$ for $1 \mathrm{~min}$, and $72^{\circ} \mathrm{C}$ for $5 \mathrm{~min}$. The PCR products were cloned and sequenced to confirm their identities.

\section{RESULTS}

\subsection{Inoculation of baculovirus into queen pupae}

To examine the infectivity of the baculovirus in the queen honeybee, we prepared a recombinant baculovirus (WT/GFP) that carried $g f p$ under the regulation of the cytomegalovirus immediateearly promoter $\left(\mathrm{P}_{\mathrm{CMV}}\right.$; Figure $1 \mathrm{a}$, top panel). $\mathrm{P}_{\mathrm{CMV}}$ is known to promote gene expression in worker honeybees (Kunieda and Kubo 2004). Before injecting the WT/GFP virus into queen honeybees, we injected a baculovirus without $g f p$ into worker pupae to confirm that the virus without $g f p$ did not induce significant fluorescence (data not shown). When the WT/GFP virus vector was inoculated into the abdomen of queen pupae at a titer of $1 \times 10^{5}$ IFU, fluorescence was detected around the injected site in all injected pupae within 3 days after inoculation. The fluorescence was limited to the injection site without extending much into the surrounding tissues (Figure 2a-d; Table I); this observation was consistent with observations of worker pupae reported by Ando et al. (2007). 
On dissecting the abdomens of the pupae, we did not detect infection in the ovaries (Figure $2 \mathrm{q}-\mathrm{t}$ ). Instead, strong fluorescence was observed in the fat bodies (Figure 2i-1). Punctate fluorescence was observed in the removed ovaries, but this fluorescence was probably from the remnant fat body cells attached to the ovaries (Figure 2q-t). All individuals injected with the virus vector at $1 \times 10^{5}$ IFU eclosed to adult queens, in which fluorescence was detected in the fat bodies, but not in the ovaries (Table I; Figure 3a-d, i-1). Transcription of $g f p$ in the fat bodies of adult queen honeybees was confirmed by an RT-PCR assay of adult queen honeybees at $24-48 \mathrm{~h}$ after eclosion (Figure 4). When the virus was injected at a higher titer $\left(1 \times 10^{6} \mathrm{IFU}\right)$, fluorescence was observed in a wider region compared with that observed on injection at $1 \times 10^{5}$ IFU (Figure $2 \mathrm{a}-\mathrm{d}, \mathrm{S} 1 \mathrm{a}-\mathrm{d}$ ). However, there was still no observable fluorescence in the ovaries (Figure S1i-1). At $1 \times 10^{6}$ IFU, only approximately half of the individuals survived to eclose (Table I), and the wings of the eclosed adults were noticeably shrunken

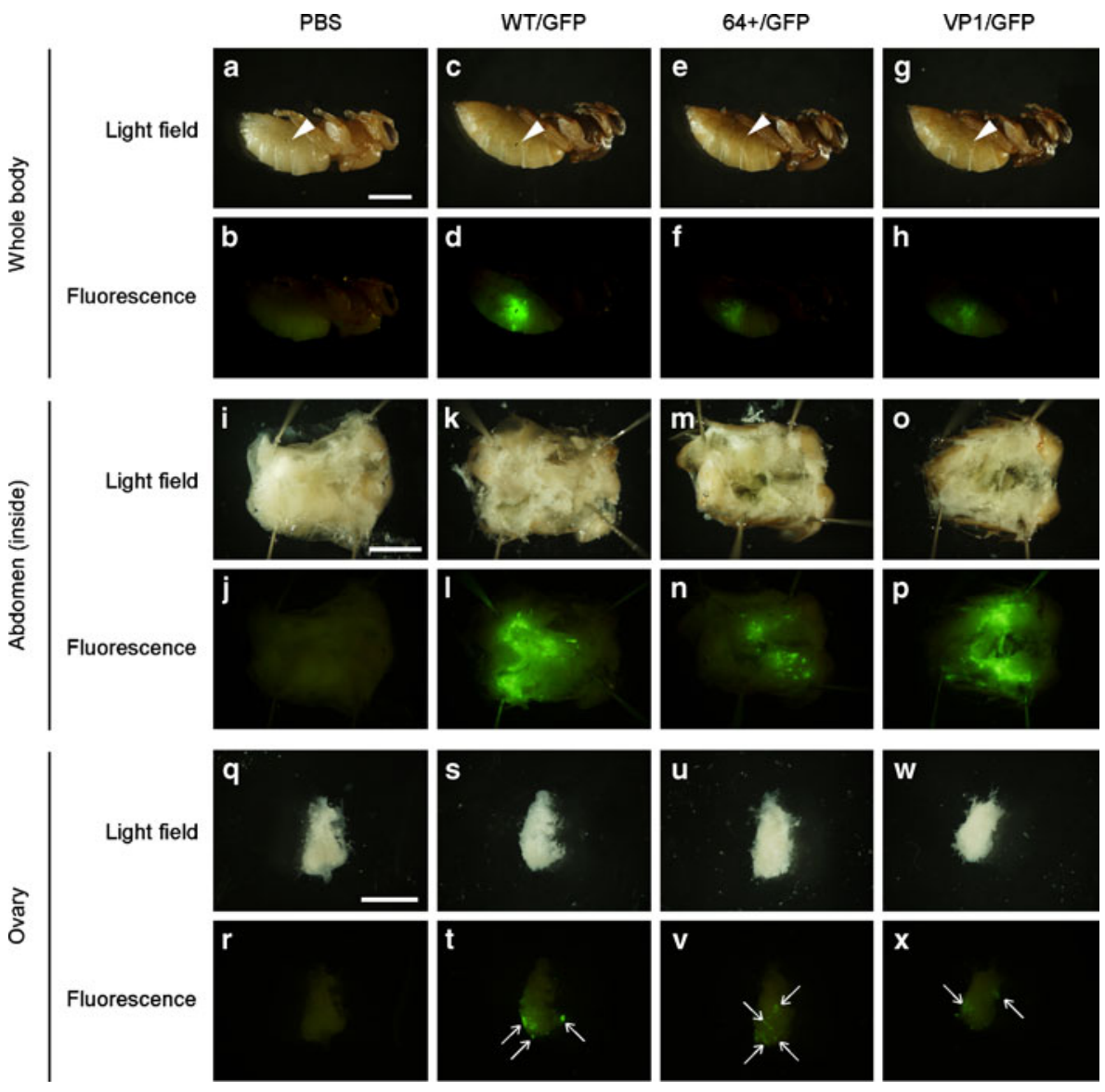

Figure 2. Queen pupae at 3 days after inoculation with baculovirus vectors at a titer of $1 \times 10^{5}$ IFU. Queen pupae were injected with PBS $(\mathbf{a}, \mathbf{b}, \mathbf{i}, \mathbf{j}, \mathbf{q}, \mathbf{r})$, WT/GFP virus $(\mathbf{c}, \mathbf{d}, \mathbf{k}, \mathbf{l}, \mathbf{s}, \mathbf{t}), 64+/ \mathrm{GFP}$ virus $(\mathbf{e}, \mathbf{f}, \mathbf{m}, \mathbf{n}, \mathbf{u}, \mathbf{v})$, or VP1/GFP virus $(\mathbf{g}, \mathbf{h}, \mathbf{o}, \mathbf{p}, \mathbf{w}, \mathbf{x})$. Arrow heads indicate the injected points. a-h Outward appearances of injected pupae. $\mathbf{i}-\mathbf{p}$ Internal views of the dissected abdominal region. $\mathbf{q}-\mathbf{x}$ Removed ovaries from injected pupae. Punctate signals on the ovaries indicated by the arrows were not derived from the ovaries but from the remnant fat body cells attached to the ovaries. Bars indicate a scale of $5 \mathrm{~mm}$. 
Table I. Eclosion rates and fluorescence in queen honeybees abdominally injected with baculovirus vectors at the pupal stage.

\begin{tabular}{lcccc}
\hline Injection & Infectious units & Eclosion (\%) & \multicolumn{2}{c}{ Fluorescence (\%) } \\
\cline { 3 - 5 } & & & In the pupal stage & After eclosion \\
\hline PBS & 0 & $8 / 8(100)$ & $8 / 9(0)$ & $0 / 8(0)$ \\
WT/GFP & $1.0 \times 10^{5}$ & $7 / 7(100)$ & $10 / 10(100)$ & $7 / 7(100)$ \\
& $1.0 \times 10^{6}$ & $5 / 9(56)$ & $8 / 8(100)$ & $5 / 5(100)$ \\
$64+/ G F P$ & $1.0 \times 10^{5}$ & $7 / 7(100)$ & $10 / 10(100)$ & $5 / 7(100)$ \\
& $1.0 \times 10^{6}$ & $5 / 9(56)$ & $8 / 8(100)$ & $7 / 7(100)$ \\
VP1/GFP & $1.0 \times 10^{5}$ & $7 / 7(100)$ & $10 / 10(100)$ & $4 / 4(100)$ \\
& $1.0 \times 10^{6}$ & $4 / 9(44)$ & & \\
\hline
\end{tabular}

(data not shown). Thus, inoculation at this titer seems to be harmful to queen pupae.

\subsection{Injection of pseudotype baculovirus vectors into queen pupae}

Expecting that GP64 overexpression might enhance baculovirus tropism in honeybee ovaries, we prepared a pseudotype baculovirus vector $(64+/ \mathrm{GFP})$ that contained an additional gp64 coding sequence under the regulation of the strong polyhedrin promoter (Figure 1a, middle panel). As another strategy to alter the infectivity of the baculovirus, we also prepared a pseudotype baculovirus (VP1/GFP) that displayed the VP1 of DWV as a fusion protein with GP64 on the surface of the baculovirus envelope (Figure 1a, bottom panel). DWV is known to infect various tissues of worker honeybees (Yue and Genersch 2005; Lanzi et al. 2006), most prominently in the pupal stage (Chen et al. 2005a), and also infect queen honeybees (Chen et al. 2005b; Williams et al. 2009). Insect picorna-like viruses including DWV resemble the mammalian picornaviruses, i.e., both have a single-stranded RNA as the genome and the form, an icosahedral capsid composed of four types of virion proteins (VP1-VP4; Lanzi et al. 2006). Since the host cell binding site is located on VP1 in mammalian picornaviruses (Fox et al. 1989; Colston and Racaniello 1994; Tate et al. 1999; Liljas et al. 2002; Estrozi et al. 2008), we hypothesized that the host cell-interacting site of DWV is also on VP1.

To confirm the GP64 overexpression and expression of the GP64-VP1 fusion protein, we analyzed the total proteins from Sf9 cells, with which the virus vectors were produced, by Western blot analysis using an anti-GP64 monoclonal antibody. The signal for GP64 was detected in $64+/$ GFP virus-infected cells at a level far higher than that in WT/GFP virusinfected cells. A band of approximately $100 \mathrm{kDa}$ (the size expected for the fusion protein of GP64 and DWV VP1) was detected from VP1/GFP virus-infected cells in addition to endogenous GP64 (Figure 1b).

We injected these pseudotype baculoviruses into the abdominal regions of queen pupae at $1 \times 10^{5}$ IFU and detected fluorescence in all pupae within 3 days of inoculation (Table I; Figure $2 \mathrm{a}, \mathrm{b}, \mathrm{e}-\mathrm{h})$. Dissection of the abdomen showed that the fat bodies emit significant fluorescence (Figure 2i, j, m-p), but the ovaries did not (Figure 2q, r, u-x). All injected individuals eclosed to adult queen honeybees (Table I), in which fluorescence was detected in the fat bodies (Figure 3a, b, e-h), but not in the ovaries (Figure 3i, j, m-p). Even when the viral titer was increased to $1 \times 10^{6}$ IFU, no fluorescence was detected in the ovaries, and approximately half of the injected pupae died just before metamorphosis (Figure S1i, i, m-p; 


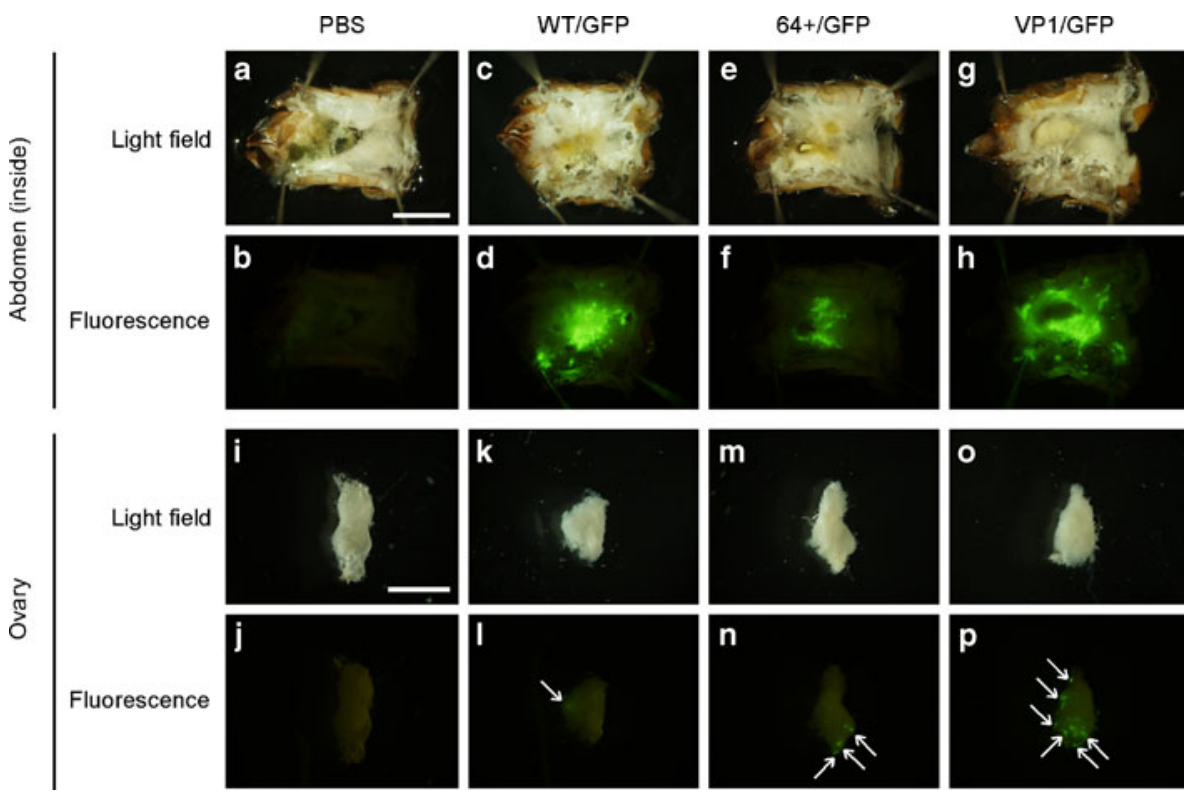

Figure 3. GFP expression in adult queen honeybees inoculated with baculovirus vectors at a titer of $1 \times 10^{5}$ IFU at the pupal stage. The queen honeybees were injected with PBS $(\mathbf{a}, \mathbf{b}, \mathbf{i}, \mathbf{j})$, WT/GFP virus $(\mathbf{c}, \mathbf{d}, \mathbf{k}, \mathbf{l}), 64+/ \mathrm{GFP}$ virus $(\mathbf{e}, \mathbf{f}, \mathbf{m}, \mathbf{n})$, or VP1/GFP virus $(\mathbf{g}, \mathbf{h}, \mathbf{o}, \mathbf{p})$. $\mathbf{a}-\mathbf{h}$ Internal views of the dissected abdominal region. $\mathbf{i}-\mathbf{p}$ Removed ovaries from adult queen honeybees. Arrows indicate punctate signals derived from the remnant fat body cells attached to the ovaries. Bars indicate a scale of $5 \mathrm{~mm}$.

Table I). These observations suggest that neither GP64 overexpression nor a surface display of DWV VP1 can effectively enhance baculovirus tropism in the ovaries.

\section{DISCUSSION}

We examined the ability of three recombinant baculoviruses to induce exogenous gene expres-

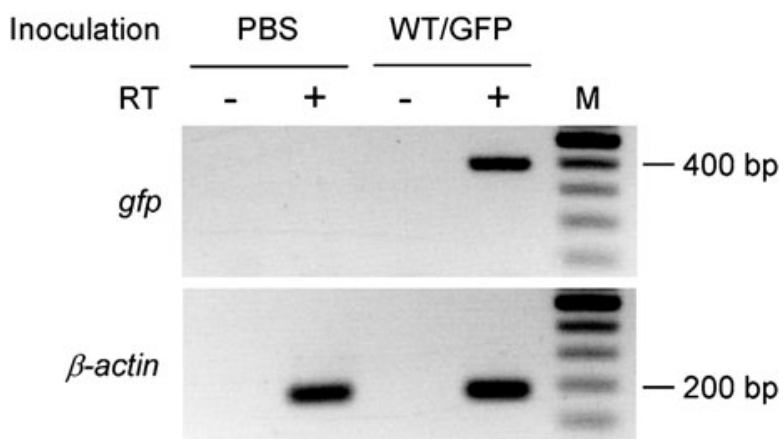

Figure 4. RT-PCR used to assess GFP expression in the fat bodies of adult queen honeybees. The queen honeybees were infected with WT/GFP at $1 \times 10^{5}$ IFU or PBS at the pupal stage, and their fat bodies were collected at 24-48 $\mathrm{h}$ after the final ecdysis. Bands of expected size were amplified from cDNA synthesized with reverse transcriptase $(\mathrm{RT}+)$, but not from negative controls ( $\mathrm{RT}-$ ). 
sion in queen honeybees. In all cases, no significant gene expression was detected in the ovaries, but the virus vectors did express GFP in the fat bodies (Figures 2, 3, and S1). Some genes expressed in the fat body, such as vitellogenin and factors of insulin-like signaling pathway, have been suggested to be involved in caste differentiation (Seehuus et al. 2006; Corona et al. 2007). The baculovirus would be a useful tool for the analyses on such interesting genes. Baculovirus could be used to express double-stranded RNA and induce RNAi in loss-of-function experiments and to overexpress exogenous genes in gain-offunction experiments.

After inoculation of the viruses, the GFPpositive region remained near the injected site and did not extend much into the surrounding tissues (Figures 2 and 3): this observation was consistent with observations of worker pupae by Ando et al. (2007). It suggests that inoculated viruses can be transduced into host cells, but they cannot spread further through secondary infection. New infectious virions seem to be rarely produced in honeybees. This property is preferable for the use of baculovirus as a gene transfer vector. In fact, baculovirus is considered to be an attractive candidate for a gene transfer vector in humans, partly because it does not cause secondary infection in mammalian cells (reviewed in Yu-Chen 2005).

We demonstrated that inoculations to pupae at $1 \times 10^{5}$ IFU caused gene transduction and allowed all injected pupae to eclose (Figure 2; Table I). We assume that the toxicity of baculovirus to honeybee pupae is relatively low probably due to the low ability to cause secondary infection. To utilize the baculovirus as a gene vector for honeybee transgenesis, an inoculation titer at which the queen honeybees are infected and survive must be used. The results of this study suggest that baculovirus has a titer that meets this necessary condition and hence, imply that methods using baculoviruses could be potentially useful for stable transgenesis if the virus is appropriately constructed such that the virus can efficiently infect and induce exogenous genes in the ovaries.
In contrast to the fat bodies, no significant fluorescence was detected in the ovaries. The viruses used might be unable to infect the ovaries or the infection levels might be, if any, very low. Although we attempted to alter the infectivity of baculovirus by overexpression of GP64 and a surface display of DWV VP1, both modifications appeared not effective. We used DWV VP1 because the surface display of a partial sequence of a mammalian picornavirus VP1 was reported to increase the infectivity of baculovirus in mammalian cells (Ernst et al. 2006; Matilainen et al. 2006). One possible explanation of the results obtained in this study is that the host-binding site of DWV might reside in virion proteins other than VP1. Although insect picorna-like viruses and mammalian picornaviruses have similar constitutions, including their sizes and icosahedral structures of the four types of virion proteins, the amino acid sequences of VP1 are distinct between the two virus groups. In addition, crystal structures of VP1 from insect picornalike viruses and picornaviruses are somewhat different (Tate et al. 1999; Liljas et al. 2002; Estrozi et al. 2008). Therefore, surface displays of other virion proteins (VP2-VP4) might effectively alter virus tropism in honeybee ovaries. Another interpretation for the failure to detect the GFP signal from the ovaries may be that the reporter gene was not expressed, despite the fact that the virus infected the ovaries. The CMV promoter that functions in the fat bodies might not functions in the ovaries. It might be worth using other promoters to study this possibility.

The queen honeybee is polyandrous and mates with males at so-called "drone congregation areas" in nature. However, instrumental insemination of virgin queen honeybees with sperm is a standard procedure (Laidlaw 1977; Harbo 1985), and honeybee colonies can be maintained in an indoor flight room for several generations (Robinson et al. 2000). Once a method for germ line transformation is developed, transgenic honeybees could be produced, which will contribute to molecular biological studies of honeybees. 


\section{ACKNOWLEDGMENTS}

We thank Ms. Mariko Miyagawa, Mr. Takuma Ishiai, and Mr. Ryo Shirai (Tamagawa University) for their help in maintaining the honeybee colonies. We also thank Dr. Mizuko Osanai-Futahashi (University of Tokyo) for the technical advice on virus preparation. This work was supported in part by Strategic Research Center Establishment Program (S0901017) and Global COE Program from the Ministry of Education, Culture, Sports, Science and Technology of Japan.

\section{Transduction de vecteurs baculovirus sur des reines d'abeilles, Apis mellifera.}

abeille / vecteur de virus / transfert de gène / transgenèse / pseudotype

\section{Zusammenfassung - Der Einsatz von Baculovirus-Vektoren zur Transduktion bei} Königinnen der Honibiene, Apis mellifera. Die europäische Honigbiene, Apis mellifera L., ist ein Modell für Studien über Sozialität bei Insekten. Verschiedene molekularbiologische Ansätze können an der Honigbioene verfolgt werden. Das Genom ist komplett sequenziert und Mikroarrays sind verfügbar für genomumfassende Expressionsstudien. Des weiteren besteht die Möglichkeit, RNA-Interferenz (RNAi) für Untersuchungen über Genfunktionen einzusetzen. Eine Methode zur Herstellung transgener Honigbienen ist jedoch noch nicht etabliert. Wir untersuchten hier die Möglichkeit, ob sich Baculoviren zur Herstellung transgener Honigbienen eignen. Baculovirus-Vektoren werden bereits erfolgreich in der Produktion transgener Insekten, wie zum Beispiel des Seidenspinners, eingesetzt. Wir stellten ein Baculovirus her, das ein grün fluoreszierendes Protein (GFP) als Reportergen enthält (Abb. 1) und inokulierten dieses in das Abdomen von Puppen. Fluoreszenz war in der Umgebung des Injektionsorts bereits innerhalb von drei Tagen detektierbar (Abb. 2). Nach Dissektion des Abdomens der Puppen fanden wir dass das GFP-Gen zwar im Fettkörper, jedoch nicht in den Ovarien exprimiert war (Table I; Abb. 2, S1). Alle mit einem Baculovirus-Titer von $1 \times 10^{5}$ Infektionseinheiten inokulierten Puppen entwickelten sich zu adulten Königinnen, in denen die Fluoreszenz nach wie vor im Fettkörper, jedoch nicht in den Ovarien zu finden war (Table I; Abb. 3 und 4). Um den Infektionsgrad des Virus zu erhöhen und das Zielgen in den Ovarien zu exprimieren, stellten wir zwei andere Baculoviren her (Abb. 1). Ein Virus überexprimierte GB64, ein Protein, das für die Anheftung und das Eindringen des Virus in Wirtszellen von Bedeutung ist. Das andere Virus enthielt ein Kapselprotein des FlügeldeformationsVirus (DWV), das Honigbienen natürlicherweise befällt. Nach Injektion dieser Viren zeigte sich, dass auch diese Viren vorzugsweisen den Fettkörper, befielen, jedoch nicht in die Ovarien eingedrungen waren (Table I; Abb. 2, 3, und S1).

Die Ergebnisse dieser Studie weisen darauf hin, dass Baculoviren für Untersuchungen von Genfunktionen in Fettkörperzellen geeignet sein können. Obwohl keines der drei Baculoviren die Expression des GFP-Reportergens in den Ovarien ermöglichte, besteht dennoch die Möglichkeit, Baculoviren für potentiell stabile Transgenesis bei Honigbienen einzusetzen, wenn sie so modifiziert werden können, dass sie effizient die Expression exogener Gene in den Ovarien induzieren.

\section{Honigbiene / Virusvektor / Gentransfer / Trans- genesis / Pseudotypus}

\section{REFERENCES}

Aase, A.L., Amdam, G.V., Hagen, A., Omholt, S.W. (2005) A new method for rearing genetically manipulated honey bee workers. Apidologie 36, 293-299

Allen, M.L., O’Brochta, D.A., Atkinson, P.W., Levesque, C.S. (2001) Stable, germ-line transformation of Culex quinquefasciatus (Diptera: Culicidae). J. Med. Entomol. 38, 701-710

Amdam, G.V., Simões, Z.L., Guidugli, K.R., Norberg, K., Omholt, S.W. (2003) Disruption of vitellogenin gene function in adult honeybees by intraabdominal injection of double-stranded RNA. BMC Biotechnol. 3, 1

Ando, T., Fujiyuki, T., Kawashima, T., Morioka, M., Kubo, T., Fujiwara, H. (2007) In vivo gene transfer into the honeybee using a nucleopolyhedrovirus vector. Biochem. Biophys. Res. Commun. 352, 335-340

Berghammer, A.J., Klingler, M., Wimmer, E.A. (1999) A universal marker for transgenic insects. Nature 402, 370-371

Bitondi, M.M., Nascimento, A.M., Cunha, A.D., Guidugli, K.R., Nunes, F.M., Simões, Z.L. (2006) Characterization and expression of the Hex110 gene encoding a glutamine-rich hexamerin in the honey bee, Apis mellifera. Arch. Insect. Biochem. Physiol. 63, 57-72 
Blissard, G.W., Wenz, J.R. (1992) Baculovirus gp64 envelope glycoprotein is sufficient to mediate $\mathrm{pH}$-dependent membrane fusion. J. Virol. 66, 6829-6835

Boublik, Y., Di Bonito, P., Jones, I.M. (1995) Eukaryotic virus display: engineering the major surface glycoprotein of the Autographa californica nuclear polyhedrosis virus (AcNPV) for the presentation of foreign proteins on the virus surface. Biotechnol. (NY) 13, 1079-1084

Chen, Y.P., Higgins, J.A., Feldlaufer, M.F. (2005a) Quantitative real-time reverse transcription-PCR analysis of deformed wing virus infection in the honeybee (Apis mellifera L.). Appl. Environ. Microbiol. 71, 436-441

Chen, Y., Pettis, J.S., Feldlaufer, M.F. (2005b) Detection of multiple viruses in queens of the honey bee Apis mellifera L. J. Invertebr. Pathol. 90, 118-121

Coates, C.J., Jasinskiene, N., Miyashiro, L., James, A.A. (1998) Mariner transposition and transformation of the yellow fever mosquito, Aedes aegypti. Proc. Natl. Acad. Sci. USA 95, 3748-3751

Colston, E., Racaniello, V.R. (1994) Soluble receptorresistant poliovirus mutants identify surface and internal capsid residues that control interaction with the cell receptor. EMBO J. 13, 5855-5862

Corona, M., Velarde, R.A., Remolina, S., Moran-Lauter, A., Wang, Y., Hughes, K.A., Robinson, G.E. (2007) Vitellogenin, juvenile hormone, insulin signaling, and queen honey bee longevity. Proc. Natl. Acad. Sci. USA 104, 7128-7133

Ernst, W., Schinko, T., Spenger, A., Oker-Blom, C., Grabherr, R. (2006) Improving baculovirus transduction of mammalian cells by surface display of a RGD-motif. J. Biotechnol. 126, 237-240

Estrozi, L.F., Neumann, E., Squires, G., Rozas-Dennis, G., Costabel, M., Rey, F.A., Guerin, D.M.A., Navaza, J. (2008) Phasing of the Triatoma virus diffraction data using a cryo-electron microscopy reconstruction. Virology 375, 85-93

Fox, G., Pary, N., Barnett, P.V., Mcginn, B., Rowlands, D. J., Brown, F. (1989) The cell attachment site on footand-mouth disease virus includes the amino acid sequence RGD (arginine-glycine-aspartic acid). J. Gen. Virol. 70, 625-637

Grossman, G.L., Rafferty, C.S., Clayton, J.R., Stevens, T.K., Mukabayire, O., Benedict, M.Q. (2001) Germline transformation of the malaria vector, Anopheles gambiae, with the piggyBac transposable element. Insect. Mol. Biol. 10, 597-604

Handler, A.M. (2001) A current perspective on insect gene transformation. Insect. Biochem. Mol. Biol. 31, 111-128

Handler, A.M. (2002) Use of the piggyBac transposon for germ-line transformation of insects. Insect. Biochem. Mol. Biol. 32, 1211-1220

Harbo, J.R. (1985) Instrumental insemination of queen bees. Am. Bee J. 125, 282-287
Hefferon, K.L., Oomens, A.G., Monsma, S.A., Finnerty, C.M., Blissard, G.W. (1999) Host cell receptor binding by baculovirus GP64 and kinetics of virion entry. Virology 258, 455-468

Honeybee Genome Sequencing Consortium (2006) Insights into social insects from the genome of the honeybee Apis mellifera. Nature 443, 931-949

Jasinskiene, N., Coates, C.J., Benedict, M.Q., Cornel, A.J., Rafferty, C.S., James, A.A., Collins, F.H. (1998) Stable transformation of the yellow fever mosquito, Aedes aegypti, with the Hermes element from the housefly. Proc. Natl. Acad. Sci. USA 95, 3743-3747

Kawashima, T., Osanai, M., Futahashi, R., Kojima, T., Fujiwara, H. (2007) A novel target-specific gene delivery system combining baculovirus and sequence-specific long interspersed nuclear elements. Virus Res. 127, 49-60

Kimura, K. (2001) Transposable element-mediated transgenesis in insects beyond Drosophila. J. Neurogenet. 15, 179-192

Kucharski, R., Maleszka, J., Foret, S., Maleszka, R. (2008) Nutritional control of reproductive status in honeybees via DNA methylation. Science 319, 1827-1830

Kunieda, T., Kubo, T. (2004) In vivo gene transfer into the adult honeybee brain by using electroporation. Biochem. Biophys. Res. Commun. 318, 25-31

Laidlaw, H.H. (1977) Instrumental insemination of honey bee queens. Dadant and Sons, Hamilton

Laidlaw, H.H., Page, R.E. (1997) Queen rearing and bee breeding. Wicwas, Cheshire

Lanzi, G., de Miranda, J.R., Boniotti, M.B., Cameron, C. E., Lavazza, A., Capucci, L., Camazine, S.M., Rossi, C. (2006) Molecular and biological characterization of deformed wing virus of honeybees (Apis mellifera L.). J. Virol. 80, 4998-5009

Liljas, L., Tate, J., Lin, T., Christian, P., Johnson, J.E. (2002) Evolutionary and taxonomic implications of conserved structural motifs between picornaviruses and insect picorna-like viruses. Arch. Virol. 147, 59-84

Loukeris, T.G., Livadaras, I., Arca, B., Zabalou, S., Savakis, C. (1995) Gene transfer into the medfly, Ceratitis capitata, with a Drosophila hydei transposable element. Science 270, 2002-2005

Marcus, J.M., Ramos, D.M., Monteiro, A. (2004) Germline transformation of the butterfly Bicyclus anynana. Proc. Biol. Sci. 271, S263-S265

Matilainen, H., Mäkelä, A.R., Riikonen, R., Saloniemi, T., Korhonen, E., Hyypiä, T., Heino, J., Grabherr, R., Oker-Blom, C. (2006) RGD motifs on the surface of baculovirus enhance transduction of human lung carcinoma cells. J. Biotechnol. 125, 114-126

Nunes, F.M., Simões, Z.L. (2009) A non-invasive method for silencing gene transcription in honeybees maintained under natural conditions. Insect. Biochem. Mol. Biol. 39, 157-160 
Oomens, A.G.P., Blissard, G.W. (1999) Requirement for GP64 to drive efficient budding of Autographa californica multicapsid nucleopolyhedrovirus. Virology 254, 297-314

Patel, A., Fondrk, M.K., Kaftanoglu, O., Emore, C., Hunt, G., Frederick, K., Amdam, G.V. (2007) The making of a queen: TOR pathway is a key player in diphenic caste development. PLoS ONE 2, e509

Robinson, K.O., Ferguson, H.J., Cobey, S., Vaessin, H., Smith, B.H. (2000) Sperm-mediated transformation of the honey bee, Apis mellifera. Insect. Mol. Biol. 9, 625-634

Rubin, G.M., Spradling, A.C. (1982) Genetic transformation of Drosophila with transposable element vectors. Science 218, 348-353

Seehuus, S.C., Norberg, K., Gimsa, U., Krekling, T., Amdam, G.V. (2006) Reproductive protein protects functionally sterile honey bee workers from oxidative stress. Proc. Natl. Acad. Sci. USA 103, 962-967

Sumitani, M., Yamamoto, D.S., Oishi, K., Lee, J.M., Hatakeyama, M. (2003) Germline transformation of the sawfly, Athalia rosae (Hymenoptera: Symphyta), mediated by a piggyBac-derived vector. Insect. Biochem. Mol. Biol. 33, 449-458

Tamura, T., Thibert, C., Royer, C., Kanda, T., Abraham, E., Kamba, M., Komoto, N., Thomas, J.L., Mauchamp, B., Chavancy, G., Shirk, P., Fraser, M., Prudhomme, J.C., Couble, P. (2000) Germline transformation of the silkworm Bombyx mori L. using a piggyBac transposon-derived vector. Nat. Biotechnol. 18, 81-84

Tani, H., Nishijima, M., Ushijima, H., Miyamura, T., Matsuura, Y. (2001) Characterization of cell-surface determinants important for baculovirus infection. Virology 279, 343-353
Tani, H., Limn, C.K., Yap, C.C., Onishi, M., Nozaki, M., Nishimune, Y., Okahashi, N., Kitagawa, Y., Watanabe, R., Mochizuki, R., Moriishi, K., Matsuura, Y. (2003) In vitro and in vivo gene delivery by recombinant baculovirus. J. Virol. 77, 9799-9808

Tate, J., Liljas, L., Scotti, P., Christian, P., Lin, T., Johnson, J.E. (1999) The crystal structure of cricket paralysis virus: the first view of a new virus family. Nat. Struct. Biol. 6, 765-774

Towbin, H., Staeherin, T., Gordon, J. (1979) Electrophoretic transfer of proteins from polyacrylamide gels to nitrocellulose sheets: procedure and some applications. Proc. Natl. Acad. Sci. USA 76, 43504354

Volkman, L.E., Goldsmith, P.A. (1985) Mechanism of neutralization of budded Autographa californica nuclear polyhedrosis virus by a monoclonal antibody: inhibition of entry by adsorptive endocytosis. Virology 143, 185-195

Williams, G.R., Rogers, R.E., Kalkstein, A.L., Taylor, B.A., Shutler, D., Ostiguy, N. (2009) Deformed wing virus in western honey bees (Apis mellifera) from Atlantic Canada and the first description of an overtly-infected emerging queen. J. Invertebr. Pathol. 101, 77-79

Yamamoto, M., Yamao, M., Nishiyama, H., Sugihara, S., Nagaoka, S., Tomita, M., Yoshizato, K., Tamura, T., Mori, H. (2004) New and highly efficient method for silkworm transgenesis using Autographa californica nucleopolyhedrovirus and piggyBac transposable elements. Biotechnol. Bioeng. 88, 849-853

Yu-Chen, H.U. (2005) Baculovirus as a highly efficient expression vector in insect and mammalian cells. Acta. Pharmacol. Sin. 26, 405-416

Yue, C., Genersch, E. (2005) RT-PCR analysis of Deformed wing virus in honeybees (Apis mellifera) and mites (Varroa destructor). J. Gen. Virol. 86, 3419-3424 